\title{
Survei Penempatan Pembangkit Listrik Tenaga Bayu Di Tanah Laut Berdasarkan Citra Radar Banjarmasin
}

\author{
Hanif Kurniadi ${ }^{1}$, Arifah Dwi Yuliani ${ }^{2}$, Ismah Atikah Khairunnisa ${ }^{3}$, Syadza Siskayani \\ Putri $^{4}$, Eko Wardoyo ${ }^{5}$, Imma Redha Nugraheni ${ }^{6}$ \\ 1,6 Sekolah Tinggi Meteorologi Klimatologi dan Geofisika, Jalan Perhubungan I No.5 Pondok \\ Betung, Pd. Aren, Tangerang Selatan \\ 5 Badan Meteorologi Klimatologi dan Geofisika, Jl. Angkasa I No.2 Kemayoran, Jakarta Pusat, DKI \\ Jakarta
}

Email: hanifkurniadi21@gmail.com

\begin{abstract}
Abstrack :Indonesia's electricity consumption has increased every year. One way to overcome this problem is by utilizing renewable energy sources such as wind. Utilization of this energy uses wind turbines installed at locations that have met the requirements. Therefore, information on wind conditions in several layers is required by using radar products such as CAPPI, PPI, and HWIND which are processed using Rainbow 5 software and then interpreted in a daily wind speed graph. Data obtained from radar imagery of Syamsudin Noor Meteorological Station-Banjarmasin. And to determine the boundary conditions of the wind layer is determined according to the length of the turbine blades to calculate the minimum wind speed needed to drive the turbine blades. The results of this study show that wind conditions in layers of 100 to 600 meters tend to be the same, making it difficult to determine the maximum height of the wind layer and from 7 days of the observation sample, it is found that some average wind speeds per day are $4.076923 \mathrm{~m} / \mathrm{s}, 4.777778 \mathrm{~m} / \mathrm{s}$, $4.393939 \mathrm{~m} / \mathrm{s}, 0.75 \mathrm{~m} / \mathrm{s}, 0.72973 \mathrm{~m} / \mathrm{s}, 3.678571 \mathrm{~m} / \mathrm{s}$, and $1.4375 \mathrm{~m} / \mathrm{s}$, which are known to have not met the minimum wind speed requirements for wind farm (PLTB) to produce optimal energy.
\end{abstract}

Keywords : Renewable Energy, PLTB, Weather Radar, Wind

\begin{abstract}
Abstrak :Konsumsi listrik Indonesia mengalami peningkatan setiap tahunnya. Salah satu untuk mengatasi masalah tersebut dengan memanfaatkan sumber energi terbarukan seperti angin. Pemanfaatan energi ini menggunakan turbin angin yang dipasang pada lokasi yang telah memenuhi syarat. Karena itu, diperlukan informasi kondisi angin dibeberapa lapisan dengan menggunakan produk radar seperti CAPPI, PPI, dan HWIND yang diolah menggunakan perangkat lunak Rainbow 5 lalu diintrepretasikan dalam grafik kecepatan angin harian. Data diperoleh dari citra radar Stasiun Meteorologi Kelas II Syamsudin Noor-Banjarmasin. Dan untuk menentukan kondisi batas lapisan angin ditentukan sesuai panjang dari baling-baling turbin untuk memperhitungkan kecepatan angin minimal yang diperlukan untuk menggerakkan baling-baling turbin. Hasil penelitian ini memperlihatkan kondisi angin di lapisan 100 hingga 600 meter cenderung sama, sehingga sulit untuk menentukan ketinggian lapisan angin maksimum dan dari 7 hari sebagai sampel pengamatan didapatkan beberapa kecepatan angin rata-rata perhari antara lain $4.076923 \mathrm{~m} / \mathrm{s}, \quad 4.777778 \mathrm{~m} / \mathrm{s}$, $4.393939 \mathrm{~m} / \mathrm{s}, 0,75 \mathrm{~m} / \mathrm{s}, 0.72973 \mathrm{~m} / \mathrm{s}, 3.678571 \mathrm{~m} / \mathrm{s}$, dan $1.4375 \mathrm{~m} / \mathrm{s}$ yang diketahui belum memenuhi persyaratan kecepatan angin minimum yang diperlukan Pembangkit Listrik Tenaga Bayu (PLTB) untuk menghasilkan energi yang optimal.
\end{abstract}

Kata kunci : Energi Terbarukan, PLTB, Radar Cuaca, Angin

\section{PENDAHULUAN}

Manusia tumbuh dalam ketergantungan energi, membuat energi menjadi salah satu faktor penting dalam perkembangan berkelanjutan (Azizi dkk., 2014). Data dari kementerian ESDM konsumsi listrik Indonesia setiap tahunnya terus meningkat, terakhir pada tahun 2017 
mencapai 1.012 Kilowatt per Hour $(\mathrm{KWH}) /$ kapita, naik sebesar 5,9 persen dari tahun sebelumnya (Kementerian ESDM. 2018). Fakta bahwa bahan penyumbang $45 \%$ sumber energi di seluruh dunia dihasilkan dari minyak dan pengaruh harga sumber energi sangat berpengaruh pada produktivitas ril, inflasi, dan biaya ini sangat menentukan kesejahteraan relatif masyarakat (Liun dan Sunardi, 2014). Meskipun memiliki dampak buruk bagi lingkungan, permintaan energi yang berasal dari bahan bakar fosil terus meningkat (Azizi dkk., 2014). Adanya ancaman perubahan iklim, membuat dunia untuk bekerja menggunakan energi terbarukan (Aydin dkk., 2009). Sehingga menurut Septiadi dkk. (2009) karena keterbatasannya serta dampak kerusakan lingkungan yang dihasilkan oleh sumber energi fosil, maka kita perlu melakukan penganekaragaman pemanfaatan sumber energi non fosil.

Salah satu energi terbarukan yang tidak ada habisnya dan ramah lingkungan adalah angin (Pandian dan Iyappan, 2015). Energi angin juga dapat mengurangi ketergantungan terhadap bahan bakar fosil (Global Wind Energy Council. 2013 dan Teng dan Yu. 2005). Di dunia, kapasitas pembangkit listrik tenaga angin yang terpasang menempati urutan kedua setelah pembangkit tenaga air (Renewable Global status report. 2011). Wakeyama dan Ehara (2010) menyatakan bahwa memperkenalkan pemakaian energi terbarukan adalah hal yang penting apalagi dilihat dari potensinya dalam mengurangi emisi gas rumah kaca. Seperti penelitian mereka yang dilakukan di Jepang, memanfaatkan angin dalam pengembangan energi yang bertujuan untuk mengurangi dampak gas rumah kaca akibat pengaruh gas $\mathrm{CO}_{2}$ akibat bahan bakar fosil.

Informasi mengenai energi angin merupakan hal yang mendasar yang sangat penting dalam upaya pemanfaatannya secara maksimal. Pengetahuan tentang lokasi yang tepat sumber energi angin untuk dimanfaatkan adalah hal sangat krusial. Tapi ternyata menentukan lokasi untuk pembangkit listrik tenaga angin tidaklah mudah. Penentuan lokasi ini sangat kompleks dan membutuhkan penelitian mengenai pemilihan lokasi yang yang tepat (Abdel Hamid, 2011). Potensi pembangunan sumber energi terbarukan bergantung pada geografis serta infrastruktur yang ada saat ini (Simoes dkk., 2017). Menurut Bennui dkk. (2007) pembangunan juga melibatkan berbagai macam persyaratan untuk menentukan lokasi pembangkit listrik tenaga angin seperti persyaratan fisik, ekonomi, sosial, lingkungan, dan politik, serta syarat-syarat teknis yang memungkinkan adanya perbedaan tujuan.

Penelitian yang dilakukan oleh Habibie. dkk (2011) mengenai potensi pembangkit listrik energi angin juga pernah dilakukan di Indonesia sebelumnya yaitu di daerah Maluku dan Sulawesi pada tahun 2011 yang didapatkan dengan kecepatan angin minimum $2,5 \mathrm{~m} / \mathrm{s}$ turbin angin dapat berputar dan menghasilkan listrik. Namun, kondisi ini berbeda setiap daerah tergantung kondisi geografis dan meteorologis sekitar turbin angin. Seperti penelitian yang dilakukan di Mesir yang memiliki angin minimum sebesar $5 \mathrm{~m} / \mathrm{s}$ agar dapat menggerakkan turbin (Abdel Hamid, 2011). Karenanya dalam pembangunan pembangkit listrik tenaga angin atau PLTB (Pembangkit Listrik Tenaga Bayu) perlu adanya penelitian lebih lanjut terhadap faktor-faktor sekitar tempat turbin akan dipasang. Seperti penelitian mengenai kemiringan tempat turbin, angin minimum, dan mempertimbangkan syarat tempat berdirinya turbin lainnya (Pandian dan Iyappan, 2015). Turbin angin atau kincir angin merupakan suatu alat yang mengubah energi gerak angin menjadi energi gerak berupa putaran baling-baling atau kincir, sehingga putaran kincir dapat memutar generator, yang menghasilkan energi listrik (Sumiati dan Zamri. 2013). Baling-baling merupakan komponen utama. Karena dalam prinsip pemanfaatan energi angin secara langsung melalui baling-baling. Sehingga dapat berputar dan menghasilkan energi listrik.

Dalam beberapa penelitian sebelumnya mengenai turbin angin, masih jarang yang memanfaatkan produk radar khususnya produk V. Dimana itu merupakan produk radar yang 
menunjukkan kecepatan dan arah angin pada daerah yang diamati radar. Radar juga dapat melihat kecepatan dan arah angin tiap lapisan yang diperlukan dengan sudut azimuth $360^{\circ}$ dan elevasi maksimum $19,5^{\circ}$ dari radar. Dengan memanfaatkan produk radar yang tersedia di perangkat lunak pengolah data radar seperti Rainbow untuk mengolah data dari radar gematronik, kita dapat mengetahui kondisi angin di area scanning radar baik secara vertikal maupun horizontal. Adanya fitur ini, dapat mempermudah dalam mengidentifikasi keadaan angin sesuai dengan kebutuhan.

Sehingga dalam penelitian mengenai penentuan tempat turbin angin ini, kami mengidentifikasi kondisi angin pada lapisan tertentu sesuai panjang dari baling-baling turbin untuk memperhitungkan kecepatan angin yang diperlukan untuk menggerakkan baling-baling turbin sehingga dapat digunakan dalam pertimbangan dalam penentuan penempatan turbin nantinya.

\section{METODE PENELITIAN}

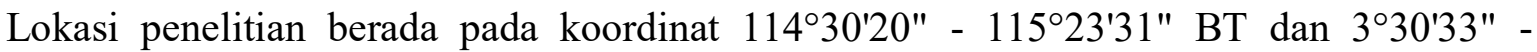
4¹1'38" LS yang merupakan wilayah kabupaten Tanah Laut, Kalimantan Selatan. Dalam penelitian ini digunakan data arah dan kecepatan angin yang diperoleh dari pengamatan radar Stasiun Meteorologi Kelas II Syamsudin Noor-Banjarmasin. Data yang digunakan adalah data satu bulan pada bulan September 2018 karena memiliki angin minimum berdasarkan perhitungan statistik dari 3 stasiun pengamatan yaitu Stasiun Meteorologi Kelas II Syamsudin Noor-Banjarmasin, Stasiun Klimatologi Kotabaru, dan Stasiun Klimatologi Banjarmasin yang dilakukan selama 2010-2018. Kecepatan angin minimum rata-rata dipilih untuk mengetahui kemampuan baling-baling berputar dalam konsdisi angin minimum untuk menghasilkan energi yang optimal pada waktu tersebut.

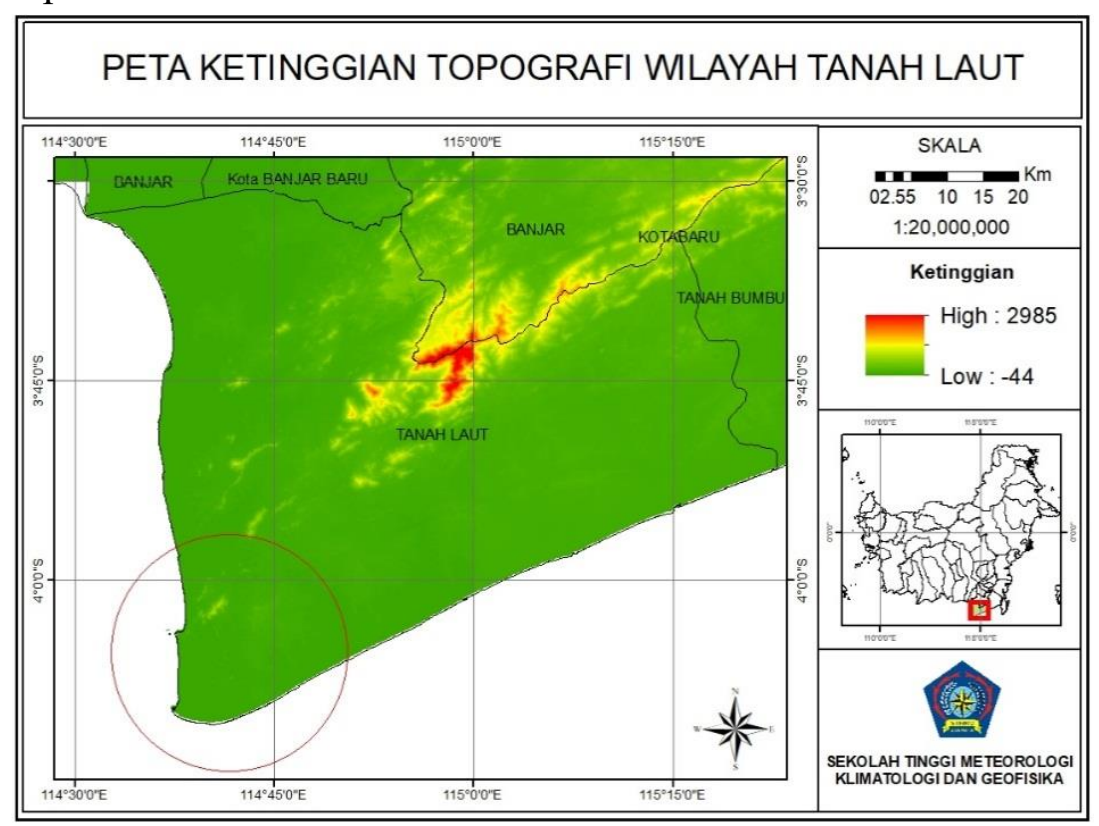

Gambar 1. Peta Lokasi Penelitian

Pada penelitian ini digunakan aplikasi pengolahan data radar Rainbow 5 dan Microsoft Excel 2016. Penggunaan Microsoft Excel 2016 untuk memudahkan peneliti dan pembaca dalam membaca data dari hasil keluaran aplikasi Rainbow 5. Data yang digunakan dari pengamatan radar Stasiun Meteorologi Kelas II Syamsudin Noor-Banjarmasin adalah data mentah (rawdata). Data mentah ini kemudian diolah menggunakan aplikasi Rainbow 5. 
Beberapa produk olahan yang digunakan pada aplikasi Rainbow 5 adalah CAPPI, PPI, dan HWIND. Pemilihan ketiga produk tersebut didasarkan pada prinsip keluaran data radar Velocity (V) yang mengukur pergerakan massa udara mendekati atau menjauhi radar kemudian untuk menentukan kecepatan angin dalam massa udara yang diamati.

\subsection{CAPPI}

Produk CAPPI atau Constan Altitude PPI dipilih untuk mengetahui pergerakan massa udara, apakah mendekati arah radar dengan indikasi berwarna hijau atau sebaliknya yaitu bergerak menjauhi radar dengan legenda berwarna merah. Algoritma CAPPI hanya menampilkan keluaran dari data yang ada pada ketinggian yang diinginkan, sehingga jika data kosong maka keluaran juga akan kosong. Untuk itu, di dalam penelitian ini kami menggunakan algoritma Pseudo CAPPI karena keluaran pada ketinggian yang memiliki data kosong dihasilkan dari nilai interpolasi data-data di sekitarnya.

\subsection{PPI}

Produk PPI atau Plan Position Indikator dipilih karena dapat mengetahui nilai kecepatan udara disetiap elevasi yang pilih. Produk ini juga dihasilkan dalam waktu yang relatif lebih cepat dibandingkan dengan scan volume. Produk ini cukup baik dalam menggambarkan kondisi cuaca pada sudut elevasi mendekati permukaan.

\subsection{HWIND}

HWIND atau Horizontal WIND merupakan produk radar yang berfungsi untuk melihat arah dan kecepatan angin. Produk HWIND menunjukkan nilai arah angin horizontal.

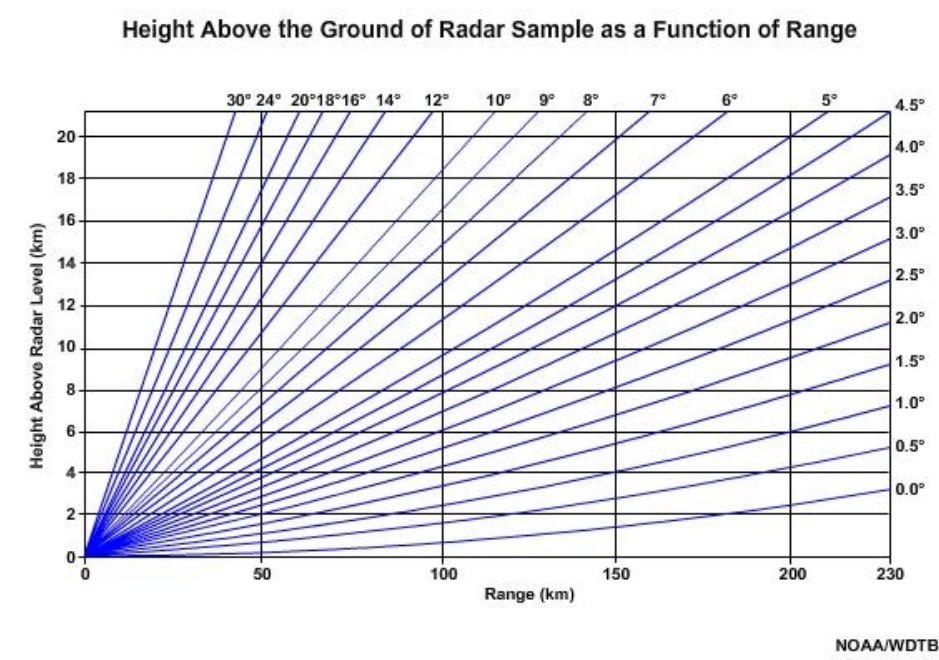

Gambar 2. Perbandingan jarak dan ketinggian beam radar pada elevasi tertentu.

Pada gambar 2 terlihat bahwa semakin jauh sinyal radar bergerak maka ketinggian setiap jalur beam radar akan semakin tinggi. Hal ini disebabkan oleh kelengkungan bumi. Penyimpangan ini dapat terjadi akibat perbedaan indeks bias udara, yang menentukan apakah sinyal radar akan dibiaskan ketika berpindah dari material satu ke material lainnya (METED). Dengan mengacu pada hubungan antara jarak dan ketinggian elevasi radar, dimana lokasi Tanah Laut yang berjarak kurang lebih $70 \mathrm{~km}$ dari radar, sehingga elevasi terendah yang terukur sekitar ketinggian $200 \mathrm{~m}$ (Gambar 2).

Disamping itu diketahui bahwa tinggi menara baja kincir angin adalah 80 meter dan panjang baling-baling adalah 57 meter maka informasi angin yang dibutuhkan pada lapisan 23 
hingga 137 meter sebelum ditambah dengan ketinggian topografi penempatan lokasi PLTB. Menurut penelitian yang dilakukan oleh Prinz. Dkk. (2005) elevasi maksimum untuk mendapatkan potensi maksimal secara teknis adalah kurang dari 2000 meter.

\section{HASIL DAN PEMBAHASAN}

Pada penelitian ini kami menggunakan tiga produk radar untuk mengintrepetasikan kondisi angin di daerah Tanah Laut yang akan di gunakan untuk pebangunan PLTB (Pembangkit Litrik Tenaga Bayu) yaitu CAPPI, PPI, dan HWIND. Masing-masing produk tersebut memiliki fungsi yang berbeda. PPI dalam penelitian ini digunakan untuk mengetahui angin sebenarnya dalam elevasi 0,5 dan 1,5 . Sedangkan CAPPI terbagi menjadi dua yaitu CAPPI dan pseudo CAPPI, dalam hal ini kami menggunakan pseudo CAPPI. Produk ini merupakan hasil interpolasi berdasarkan elevasi dari PPI untuk mengetahui kondisi angin berdasarkan ketinggian dalam satuan kilometer. Dan HWIND digunakan untuk mengetahui arah dan kecepatan angin dalam tampilan wind barb.

Seperti yang di tunjukkan pada gambar 3 kondisi angin $100 \mathrm{~m}$ dan gambar 4 angin $600 \mathrm{~m}$ yang merupakan hasil dari pseudo CAPPI memiliki arah dan kecepatan angin yang relatif sama. Hal ini terjadi akibat pseudo CAPPI merupakan hasil dari interpolasi PPI, dimana pada ketinggian tersebut masih dalam satu lingkup PPI elevasi 0,5 (gambar 4) pada posisi $70 \mathrm{~km}$ dari pusat radar seperti yang di tunjukkan gambar 2 .

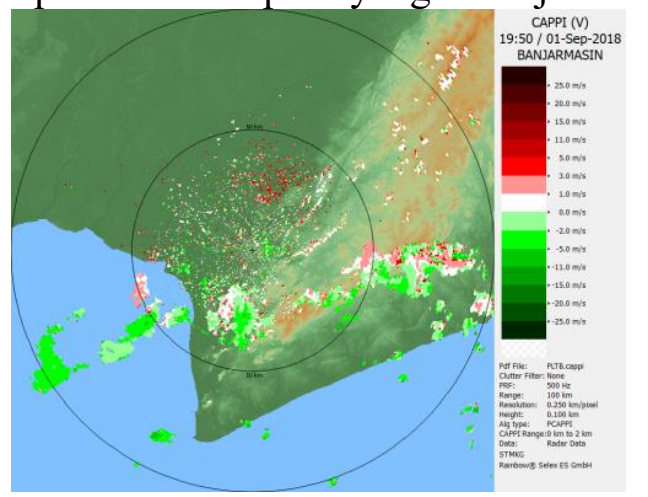

Gambar 3. Angin ketinggian 100 meter

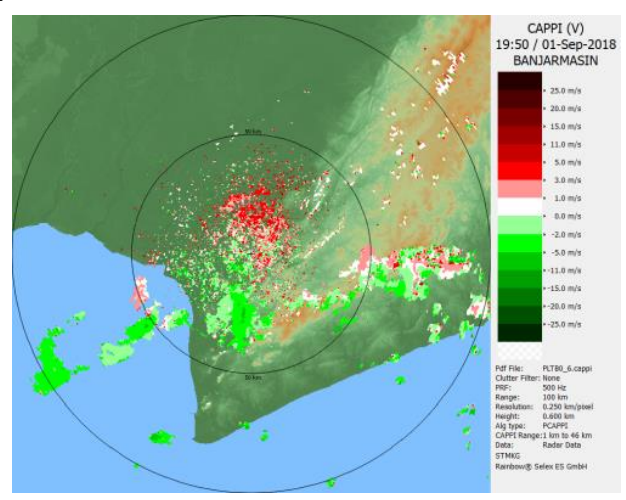

Gambar 4. Angin ketinggian 600 meter

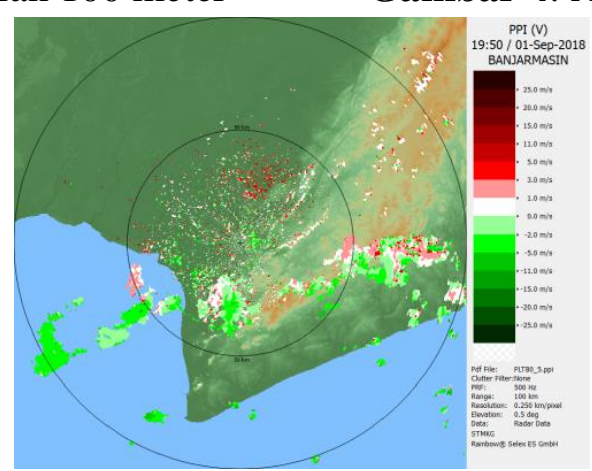

Gambar 5. Angin elevasi 0,5 
Sehingga, kondisi angin yang dihasilkan citra radar dari lapisan 100 sampai $600 \mathrm{~m}$ cenderung memiliki kondisi yang sama. Pada penelitian ini kami hanya menggunakan 7 hari untuk mengidentifikasi kondisi angin di Tanah Laut yaitu tanggal 1, 4, 5, 7, 17, 19, 20 karena
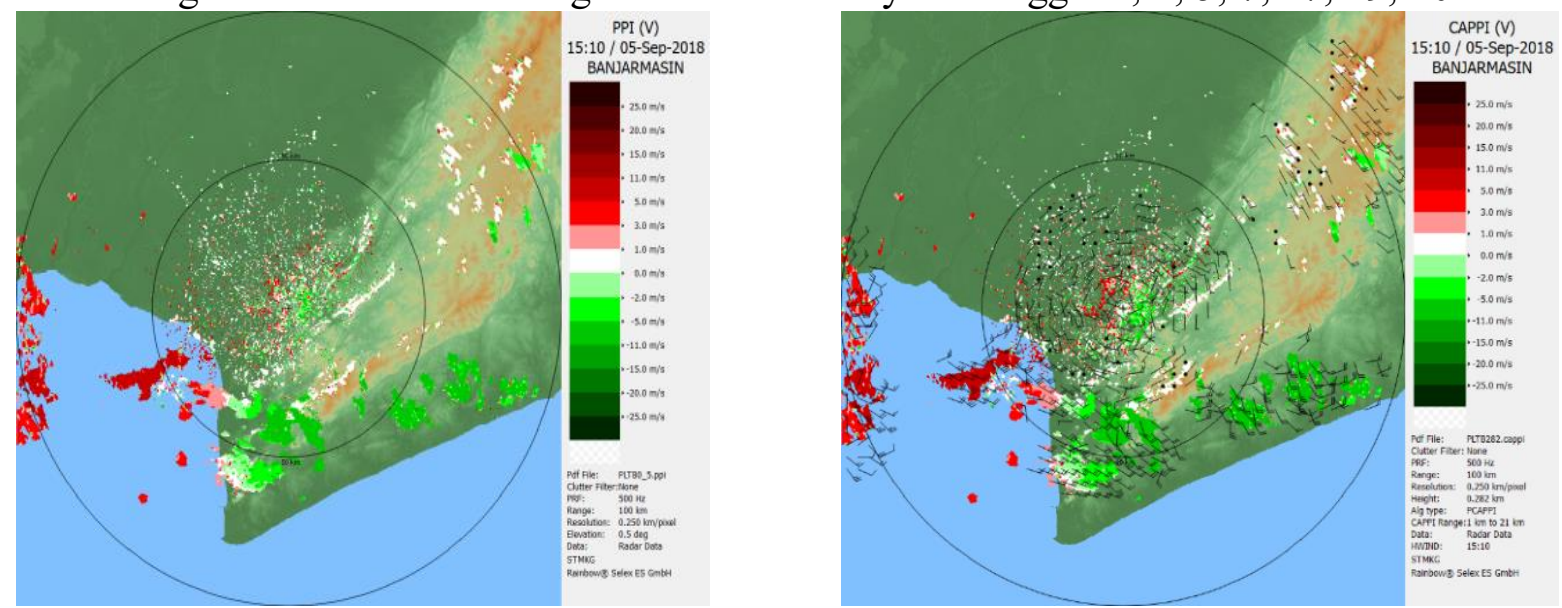

keterbatasan radar dan data. Berikut kondisi angin pada berbagai tanggal penilitian.

Gambar 6. Sampel perbandingan data PPI 0,5 (kiri) dengan pseudo CAPPI $282 \mathrm{~m}$ (kanan) tanggal 1, 4, 5, 7

Berdasarkan gambar diatas masing-masing hari menunjukkan kondisi angin sebenarnya yang di tunjukkan oleh produk PPI sama dengan produk CAPPI yang di overlay dengn produk HWIND. Dari sampel menunjukkan kondisi angin pada daerah penelitian. Adanya kesamaan citra radar tersebut berarti hasil dari produk CAPPI bisa mewakili kondisi angin sebenarnya di lapisan tertentu. Dan berikut kondisi kecepatan angin diberbagai tanggal penelitian dari citra radar yang diintrepretasi dalam bentuk grafik.

\subsection{Tanggal 1}

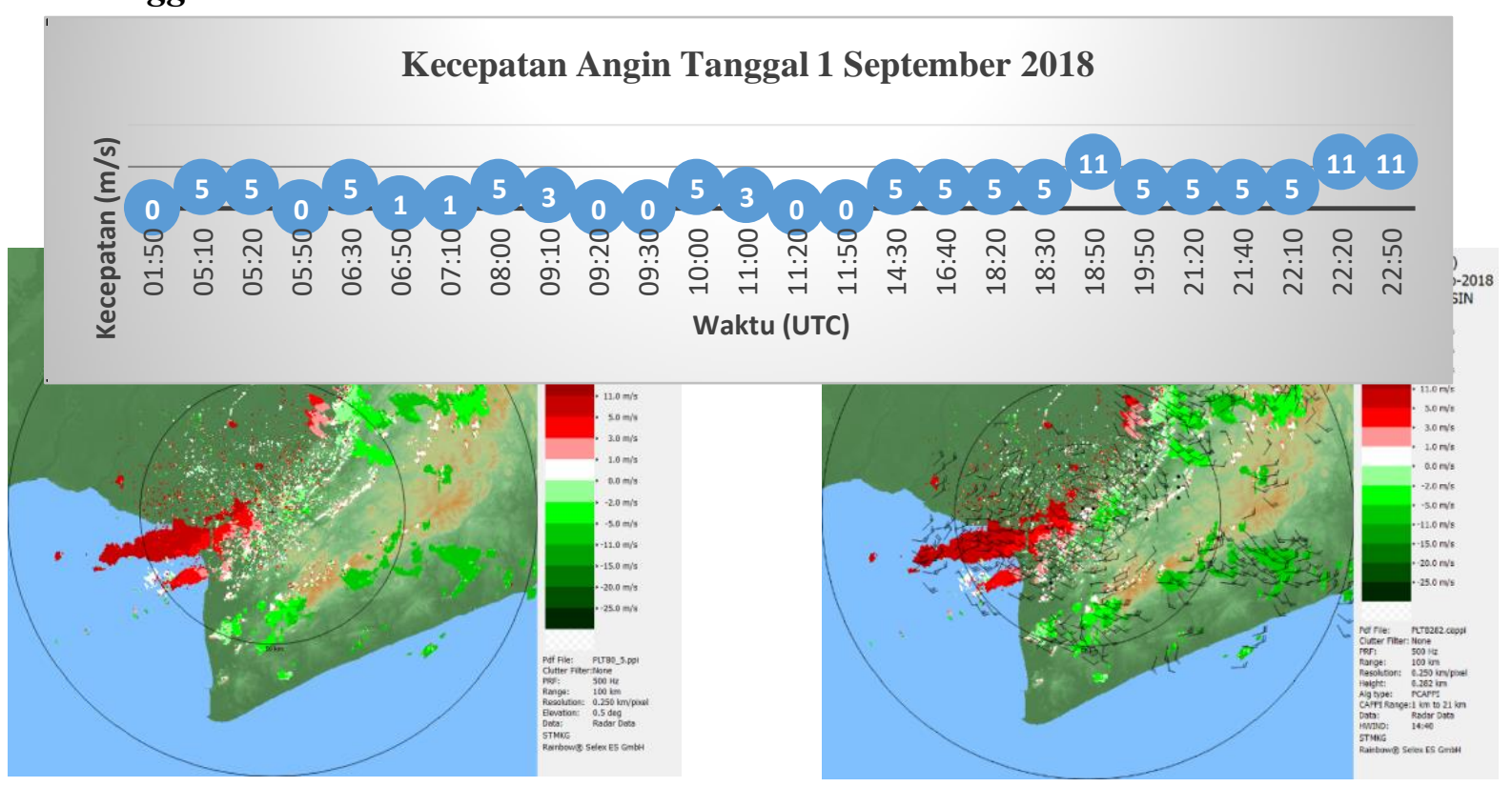

Gambar 7. Grafik nilai kecepatan tanggal 1

Berdasarkan grafik hari kecepatan angin pada tanggal 1 sebagian besar angin menunjukkan kecepatan angin $5 \mathrm{~m} / \mathrm{s}$ dengan kecepatan maksimum hari itu $11 \mathrm{~m} / \mathrm{s}$. Dan juga diperoleh rata- 
rata kecepatan angin sekitar $4.076923 \mathrm{~m} / \mathrm{s}$, dimana kondisi ini belum memenuhi batas minimum kecepatan angin yang diperlukan untuk PLTB.

\subsection{Tanggal 4}

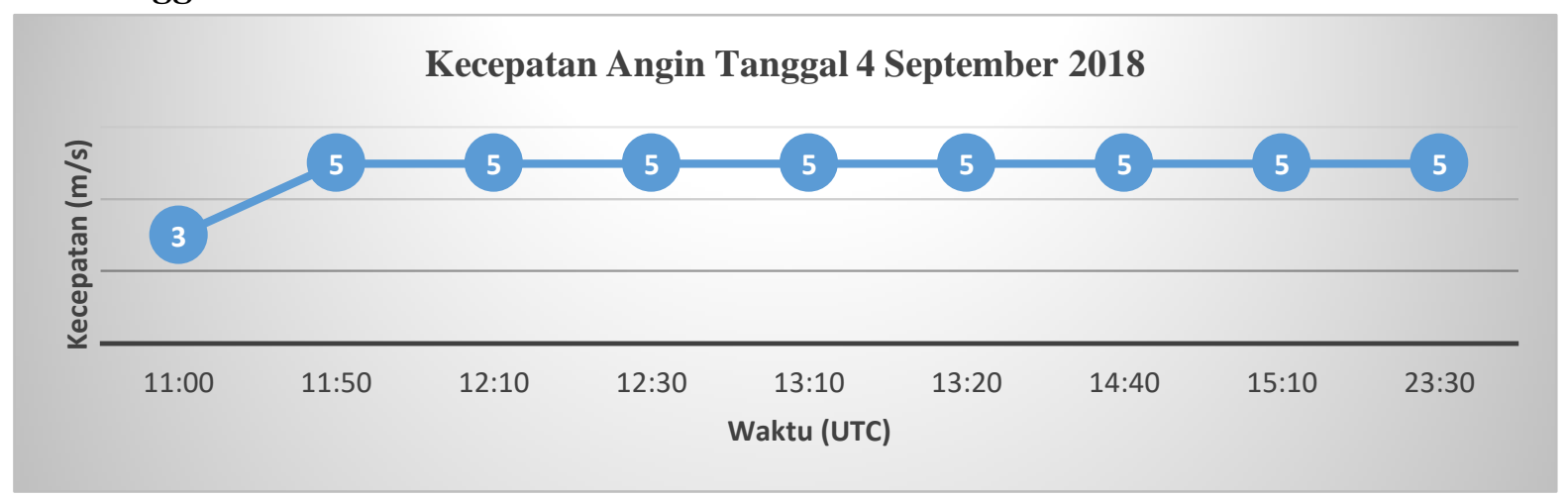

Gambar 8. Grafik nilai kecepatan tanggal 4

Berdasarkan hasil pehitungan kecepatan angin rata-rata tanggal 4 adalah 4.777778 . Hal ini menunjukkan bahwa pada tanggal 4 belum memenuhi kriteria dalam kecepatan minimum yang diperlukan PLTB untuk menghasilkan energi yang optimal.

\subsection{Tanggal 5}

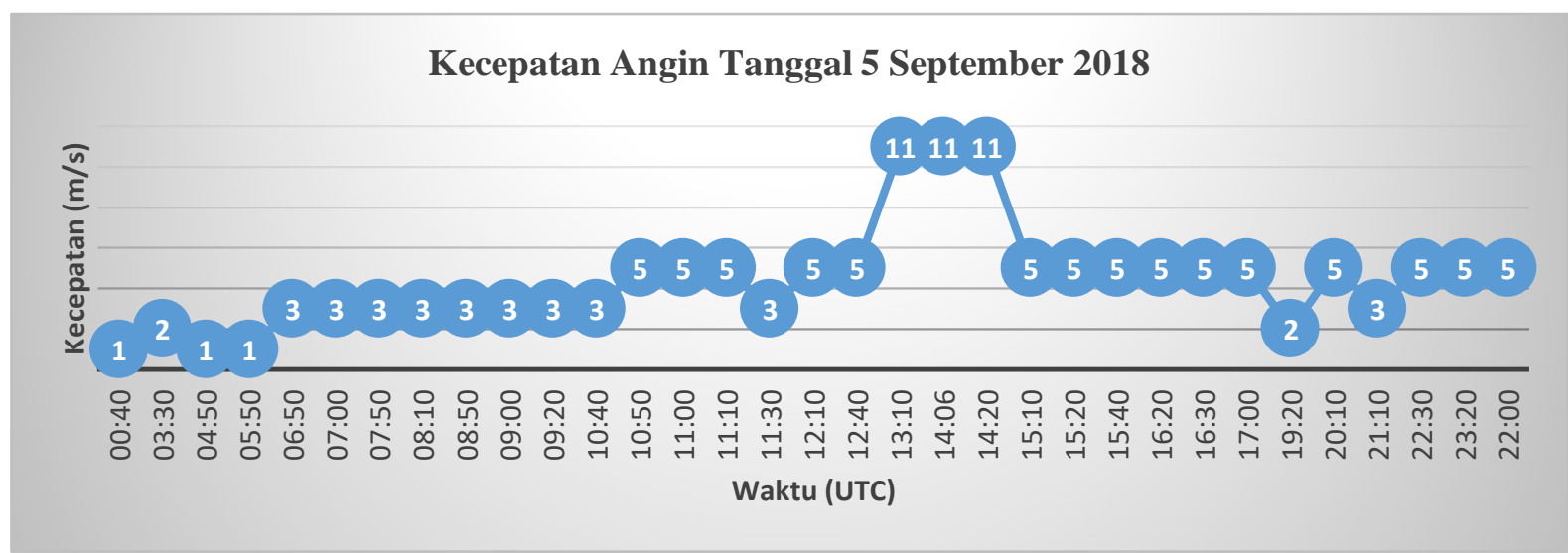

Gambar 9. Grafik nilai kecepatan tanggal 5

Berdasarkan gambar 7 terlihat 3 kecepatan maksimum angin sekitar $11 \mathrm{~m} / \mathrm{s}$ dan kecepatan minimumnya lebih banyak yaitu sekitar $3 \mathrm{~m} / \mathrm{s}$. Dari hasil perhitungan didapat kecepatan angin rata-rata tanggal 5 adalah 4.393939. Hal ini menunjukkan bahwa pada tanggal 5 belum memenuhi kriteria dalam kecepatan minimum yang diperlukan PLTB untuk menghasilkan energi yang optimal. 


\subsection{Tanggal 7}

Kecepatan Angin Tanggal 7 September 2018

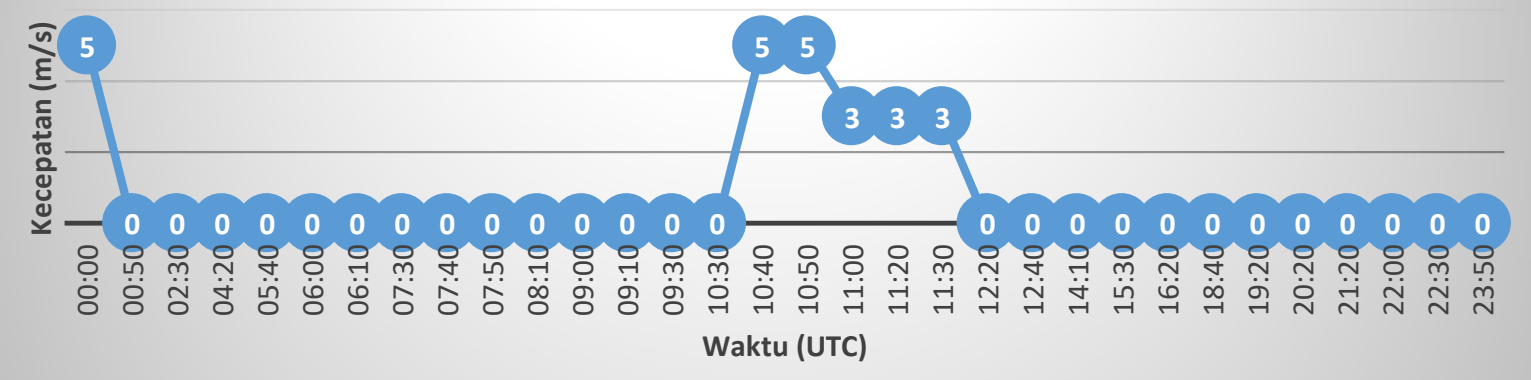

Gambar 10. Grafik nilai kecepatan tanggal 7

Berdasarkan hasil pehitungan kecepatan angin rata-rata tanggal 7 adalah 0.75 . Nilai ini sangat kurang untuk mencapai nilai kecepatan minimum yang diperlukan PLTB untuk menghasilkan energi yang optimal. Terdapat banyak nilai 0 , hal ini mungkin disebabkan karena tidak adanya partikel yang mengembalikkan energi yang dipancarkan radar ataupun arah gerak partikel yang tegak lurus terhadap beam. Sehingga radar mengira nilai tersebut adalah 0 .

\subsection{Tanggal 17}

\section{Kecepatan Angin Tanggal 17 September 2018}

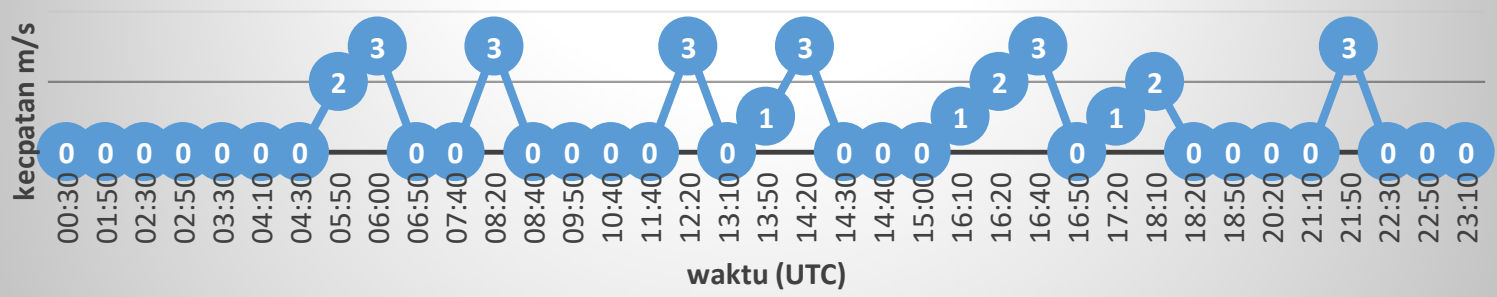

Gambar 11. Grafik nilai kecepatan tanggal 17

Tanggal 17 hampir sama dengan tanggal 7 terdapat banyak kecepatan angin yang bernilai 0 . Berdasarkan hasil pehitungan kecepatan angin rata-rata tanggal 17 adalah 0.72973 . Hal ini menunjukkan bahwa pada tanggal 17 belum memenuhi kriteria dalam kecepatan minimum yang diperlukan PLTB untuk menghasilkan energi yang optimal dengan batas minimum kecepatan $5 \mathrm{~m} / \mathrm{s}$. 


\subsection{Tanggal 19}

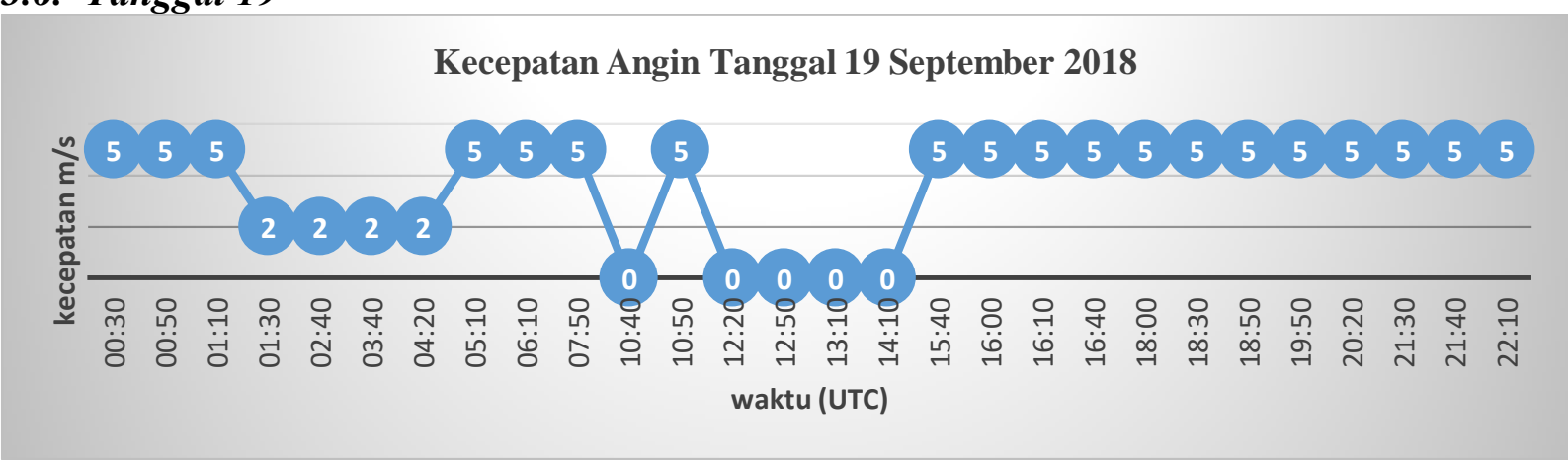

Gambar 12. Grafik nilai kecepatan tanggal 19

Walaupun terlihat kabanyakan nilai kecepatan angin diatas $5 \mathrm{~m} / \mathrm{s}$, namun berdasarkan hasil pehitungan kecepatan angin rata-rata tanggal 19 adalah $3.678571 \mathrm{~m} / \mathrm{s}$. Nilai ini belum menunjukkan bahwa pada tanggal 19 belum memenuhi kriteria dalam kecepatan minimum yang diperlukan PLTB untuk menghasilkan energi yang optimal dengan batas minimum.

\subsection{Tanggal 20}

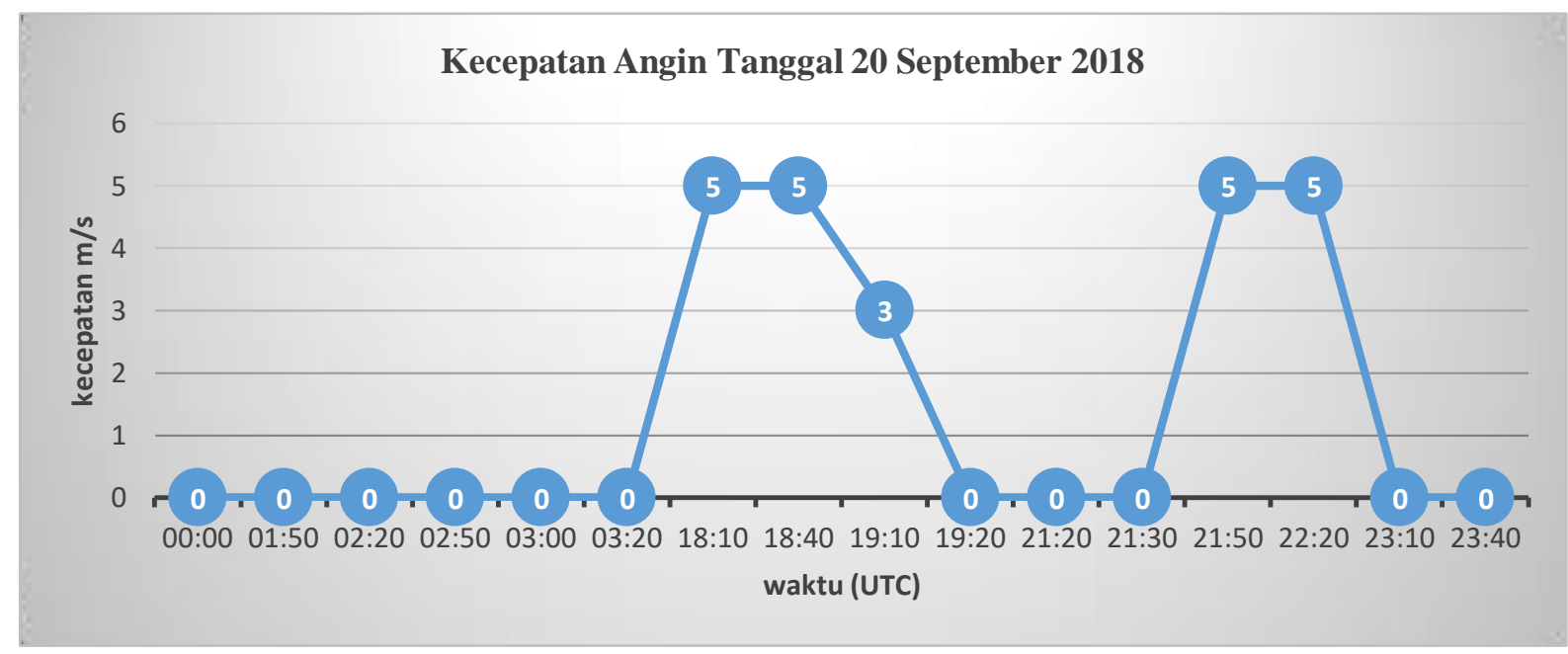

Gambar 13. Grafik nilai kecepatan tanggal 20

Terlihat kabanyakan nilai kecepatan angin diatas minimum yaitu $0 \mathrm{~m} / \mathrm{s}$. Hal ini sama dengan tanggal 7 dan 17 dimungkinkan karena tidak adanya partikel yang mampu membalikkan energi ke radar atau terdapat zero isodop. Sehingga radar membaca di wilayah tersebut mempunyai nilai kecepatan 0 . Dan berdasarkan hasil pehitungan kecepatan angin rata-rata tanggal 20 adalah $1.4375 \mathrm{~m} / \mathrm{s}$. Nilai ini belum menunjukkan bahwa pada tanggal 20 belum memenuhi kriteria dalam kecepatan minimum yang diperlukan PLTB untuk menghasilkan energi yang optimal.

\section{KESIMPULAN}

Berdasarkan hari pengamatan pada bulan september dengan citra radar diperoleh kecepatan angin rata-rata semua tanggal tidak memenuhi kriteria minimum untuk memenuhi syarat PLTB yang ideal. Seperti pada tanggal 1 diperoleh kecepatan angin rata-rata $4.076923 \mathrm{~m} / \mathrm{s}$, tanggal 4 yaitu $4.777778 \mathrm{~m} / \mathrm{s}$, tanggal 5 bernilai $4.393939 \mathrm{~m} / \mathrm{s}$, tanggal 7 dengan kecepatan 0,75 , tanggal 17 yakni $0.72973 \mathrm{~m} / \mathrm{s}$, tanggal 19 yaitu $3.678571 \mathrm{~m} / \mathrm{s}$, dan tanggal 20 bernilai 
$1.4375 \mathrm{~m} / \mathrm{s}$. Hal ini berarti pada wilayah Tanah Laut kurang cocok untuk berdirinya PLTB karena pada bulan dengan kecepatan angin terendah (September) memiliki kecepatan rata-rata kurang dari $5 \mathrm{~m} / \mathrm{s}$ yang menyebabkan kurang optimalnya kinerja PLTB dalam menghasilkan energi. Selain itu, dalam penilitian didapatkan bahwa kondisi angin pada lapisan kajian yaitu 100 hingga 600 meter dengan menggunakan pseudo CAPPI menunjukkan bahwa kondisi angin cenderung sama. Kondisi ini sulit untuk menentukan posisi ketinggian PLTB dari permukaan tanah untuk mendapatkan kecepatan angin yang optimal di lapisan tertentu.

\section{SARAN}

Terdapat banyak jam dalam beberapa hari yang memiliki kecepatan $0 \mathrm{~m} / \mathrm{s}$. Hal ini karena radar hanya menghitung kecepatan angin secara radial dan juga menangkap informasi jika ada partikel yang dapat mengembalikan energi yang di pancarkan radar. Sehingga dalam mengitrepetasikan angin cenderung underestimate. Pada penilitian selanjutnya dalam mengitrepetasikan angin perlapisan dapat menambahkan metode yang lain seperti dengan satelit, radiosonde, ataupun sensor lainnya yang dapat menghitung kondisi atmosfer secara vertikal.

\section{DAFTAR PUSTAKA}

Abdel Hamid, R. H. (2011). A GIS-DSS for wind farms industry in Egypt. 2011 International Conference \& Utility Exhibition on Power and Energy Systems: Issues and Prospects for Asia (ICUE).

Aydin, N. Y., Kentel, E., \& Duzgun, S. . (2010). GIS-based environmental assessment of wind energy systems for spatial planning: a case study from Western Turkey. Renewable and Sustainable Energy Reviews, 14(1), 364-373.

Azizi, A., Malekmohammadi, B., Jafari, H. R., Nasiri, H., \& Amini Parsa, V. (2014). Land suitability assessment for wind power plant site selection using ANP-DEMATEL in a GIS environment: case study of Ardabil province, Iran. . Environmental Monitoring and Assessment, 186(10), 6695-6709.

Bennui, A., Rattanamanee, P., Peutpaiboon, U. (2007). Site Selection For Large Wind Turbine Using GIS. PSU-UNS International Conference on Engineering and Environment (hal. 561-566). Songkhla: ICEE.

ESDM. (2018, 1 11). Inilah Konsumsi Listrik Nasional. Diambil kembali dari Kata Data: https://databoks.katadata.co.id/datapublish/2018/01/11/inilah-konsumsi-listriknasional

Habibie, M. N., Sasmito, A., Kurniawan, R. (2011). Kajian Potensi Energi Angin Di Wilayah Sulawesi Dan Maluku. Jurnal Meteorologi Dan Geofisika, 12(2), 181-187.

Liun, E., Sunardi. (2014). Perbandingan Harga Energi Dari Sumber Energi Baru Terbarukan Dan Fosil. Jurnal Pengembangan Energi Nuklir, 16(2), 119-130.

Pandian, P. K., Iyappan, L. (2015). Developing A Geospatial Based Approach To Locate Wind Farms In Pollachi Taluk, Tamil Nadu, India. International Journal of Technical Research and Application, 12(1), 30-34.

Prinz, T., Biberacher, M., Gadocha, S., Mittlböck, M., Schardinger, I., \& Zocher, D. (2005). Energie und Raumentwicklung - Räumliche Potenziale Erneuerbarer Energieträger (Energy and Spatial Development - Spatial explicit renewable energy potential). Österreichische Raumordnungskonferenz (ÖROK) Schriftenreihe, 178.

Septiadi, D. dkk. (2009). Proyeksi Potensi Energi Surya Sebagai Energi Terbarukan (Studi Wilayah Ambon Dan Sekitarnya). Jurnal Meteorologi Dan Geofisika, 10(1), 22-28. 
Simoes, S., Zeyringer, M., Huld, T., Schmidt, J., \& Mayr, D. (2013). The impact of location on competitiveness of wind and PV electricity generation - Case study for Austria. 2013 10th International Conference on the European Energy Market (EEM).

Sumiati, R., \& Zamri, A. (2013). Rancangan Bangun Miniatur Turbin Angin Pembangkit Listrik Untuk Media Pembelajaran. Jurnal Teknik Mesin, 3(2), 1-8.

Teng, J., \& Yu, C. (2005). Assessments for the Impacts and Benefits of Wind Farm Placement. 2005 IEEE Region 10 Cenference (hal. 1-6). IEEE.

Wakeyama, T.Ehara, S. (2010). Potential estimation of renewable energy resource in Tohoku area and Tokyo metropolitan, Japan. International Conference on Environmental Engineering and Applications., 44-48. 